\section{$\underset{\substack{\text { hommes } \\ \text { \& migrations }}}{ }$}

\section{Hommes \& migrations}

Revue française de référence sur les dynamiques

migratoires

1306 | 2014

Ecriture et migration

\title{
City of dream
}

Documentaire français 2013 de Steve Faigenbaum

\section{Anaïs Vincent}

\section{(2) OpenEdition \\ 1 Journals}

\section{Édition électronique}

URL : http://journals.openedition.org/hommesmigrations/2859

DOI : 10.4000/hommesmigrations.2859

ISSN : 2262-3353

\section{Éditeur}

Musée national de l'histoire de l'immigration

\section{Édition imprimée}

Date de publication : 1 avril 2014

Pagination : 160-161

ISBN : 978-2-919040-27-8

ISSN : 1142-852X

Référence électronique

Anaïs Vincent, «City of dream », Hommes \& migrations [En ligne], 1306 | 2014, mis en ligne le 01 août 2014, consulté le 22 septembre 2020. URL : http://journals.openedition.org/hommesmigrations/2859 ; DOI : https://doi.org/10.4000/hommesmigrations.2859

Ce document a été généré automatiquement le 22 septembre 2020.

Tous droits réservés 


\title{
City of dream
}

Documentaire français 2013 de Steve Faigenbaum

\author{
Anaïs Vincent
}

1 Detroit, État du Michigan, ancien fleuron de l'industrie automobile, est devenu une ville fantôme. Cimetière du rêve américain, la ville incarne la limite du capitalisme. Sa faillite progressive jusqu'à la banqueroute a conduit à un exode massif de sa population.

2 Après vingt-cinq ans d'absence, le cinéaste Steve Faigenbaum revient dans sa ville natale à l'occasion du décès de son père. Il y retrouve des cousins, des oncles et tantes et ses souvenirs d'enfance. Il raconte la ruine de cette cité. Se mêlent alors l'histoire personnelle de sa famille d'immigrés juifs polonais et la grande Histoire. De l'apogée au déclin de cet empire, il nous conduit dans le labyrinthe de la mémoire. Images d'archives familiales, publicités, reportages et films institutionnels d'époque illustrent ces réminiscences fragiles. Ses recherches le mènent vers les mouvements migratoires successifs qui peuplèrent et dépeuplèrent cette cité symbole de l'hystérie capitaliste.

Pendant la première moitié du $\mathrm{XX}^{\mathrm{e}}$ siècle, Detroit, ville industrielle par excellence où prospèrent les trois géants de l'automobile (General Motor, Ford et Chrysler), connaît un besoin croissant de main-d'œuvre. En plein essor, elle attire les immigrés européens contraints de fuir la guerre. Les grands-parents du réalisateur, de modestes ouvriers polonais, ont cru aux promesses du rêve américain. Les Noirs des États du Sud sont également attirés par ces nouveaux emplois bien payés. Grâce à cette croissance industrielle, de pauvres ouvriers agricoles peuvent être embauchés dans l'industrie et devenir ainsi propriétaires terriens.

4 Mais, depuis 1945, avec l'automatisation et les tensions raciales, Detroit n'a cessé de décliner. Les usines se délocalisent dans le sud du pays, le chômage augmente, alors que les immigrés afro-américains continuent d'y élire domicile. Les violences interraciales et la ségrégation économique attisent les haines.

5 En 1967, la révolte des Noirs partie de la $12^{\mathrm{e}}$ rue éclate et durera cinq jours, faisant de nombreux blessés. Ces violences amènent la population blanche à se déplacer vers les banlieues. On parle alors de "white flight". En un demi-siècle, Detroit perd la moitié de 
sa population. On la surnomme "shrinking city", la ville qui rétrécit". Les traces des émeutes et les stigmates du chômage l'ont transformée durablement.

Comme beaucoup, Steve Faigenbaum a préféré fuir et reconstruire ailleurs. D'un regard pessimiste, il observe aujourd'hui les ruines de ce passé glorieux. L'espoir d'un avenir radieux s'est évanoui, ne subsistent que les squelettes des maisons abandonnées, vestiges d'un rêve.

7 Alors qu'il brigue un second mandat aux prochaines élections, le gouverneur républicain du Michigan Rick Snyder porte toute son attention sur la redynamisation de cette ville portuaire. Il a déclaré en février dernier vouloir faire appel à une immigration hautement qualifiée pour redresser l'économie. Il propose de délivrer 500000 visas en cinq ans. Cette politique d'immigration choisie à l'échelle municipale pose problème. Comment contraindre ces nouveaux arrivants à rester dans la cité ? Ne seront-ils pas une source de nouvelles tensions au sein de la population ${ }^{2}$ ?

8 Avec ce documentaire sensible, le cinéaste-archéologue exhume avec délicatesse les fantômes du passé et propose une relecture pertinente de l'effondrement d'un mythe. City of dreams, Detroit une histoire américaine sortira en salle le 9 juillet prochain.

\section{NOTES}

1. Allan Popelard, Paul Vannier, "Detroit, la ville afro-américaine qui rétrécit", in Le Monde diplomatique, janvier 2014.

2. "Detroit's Immigration Solution", in The New York Times, 5 février 2014. 